\title{
Synthesis, Characterization and Antimicrobial Activity of Novel Acrylic Copolymers
}

\author{
Mitul B. Dolia, Umesh S. PAtel, Arabinda Ray, and Rajni M. PATEL ${ }^{\dagger}$ \\ Department of Chemistry, Sardar Patel University, Vallabh Vidyanagar-388120, Gujarat India
}

(Received May 30, 2005; Accepted October 10, 2005; Published February 15, 2006)

\begin{abstract}
Copolymers of monomers 4-chloro-3-methyl phenyl methacrylate (CMPM) and methyl methacrylate (MMA) were synthesized with different monomer feed ratios using 2,2'-azobisisobutyronitrile (AIBN) as initiator in toluene at $70^{\circ} \mathrm{C}$. The copolymers were characterized by IR-spectroscopy and their compositions were determined by ultraviolet (UV) and ${ }^{1} \mathrm{H}$ NMR spectroscopy. The linearization method of Fineman-Ross and Kelen-Tudos were employed to calculate the monomer reactivity ratio. Average molecular weight and polydispersity index were obtained by gel permeation chromatography (GPC). Thermogravimetric analysis (TGA and DTA) of copolymers were carried out under a nitrogen atmosphere. Antimicrobial effects of the homo and copolymers were also investigated for various microorganisms such as bacteria, fungi and yeast. [DOI 10.1295/polymj.38.159]

KEY WORDS Antimicrobial Activity / Copolymerization / Reactivity Ratio / Thermal Properties / Gel Permeation Chromatography (GPC) /
\end{abstract}

Many polymers with reactive functional groups are now being synthesized, tested and used not only for their macromolecular properties but also for the properties of functional groups. These groups provide an approach to a subsequent modification of the polymer for specific end applications. ${ }^{1}$ Acrylic and methacrylic esters are readily polymerized or copolymerized with a wide range of other monomers. The copolymers of acrylic and methacrylic esters have found use in various applications..$^{2-4}$ Due to their varied applications, chlorine containing phenyl methacrylate and its polymers have received considerable attention in recent years. ${ }^{5,6}$ These chemicals find application as biocides also. Many chlorine containing polymers possessing antimicrobial property have been reported. ${ }^{7,8}$ Phenyl acrylate polymer are relatively newly developed materials compared to the commercial polymers such as vinylic, acryl amides, alkyl acrylates etc. Phenyl acrylates are considered as reactive monomers primarily because of the presence of the aromatic ring. ${ }^{9}$ The copolymers of phenyl acrylate and methacrylate exhibit good adhesive characteristics. ${ }^{10}$ Incorporation of photosensitive group is expected to enhance the usage of methyl methacrylate copolymers in microlithography due to improvement in the mechanical properties without affecting thermal performance. ${ }^{11}$

Erol and coworkers have prepared new methacrylate monomers, their derivatives and polymers. These authors have also investigated biological activity of these polymers and they showed good biological activity. ${ }^{12,13}$

Reactivity ratios are among the most important parameters for determination of copolymer composition and they offer information about the relative reactivity of monomer pairs. Many reports have been published on the correlation between the reactivity ratio of vinyl monomers and extent of radical polymerization and copolymerizations. ${ }^{14,15}$ The distribution of protons in the two units is an important means of distinguishing monomers in the copolymerization. The aliphatic protons of both the monomers are almost indistinguishable. Narsinhaswamy ${ }^{16}$ et al. proposed a method for the determination of copolymer composition in the copolymer of phenyl methacrylate and glycidyl methacrylate from ${ }^{1} \mathrm{H}$ NMR data.

In continuous to our work on copolymers of CMPM and 8-Quinolinyl methacrylate, ${ }^{17}$ it was thought appropriate to synthesize copolymers of CMPM with MMA and examine their bioactivity. This investigation will help to understand the role of moieties other than chlorine in imparting antimicrobial activity to a polymer. We report here the synthesis and characterization of monomers CMPM and MMA, their homo polymers and copolymers using different feed ratio. The copolymer composition was obtained by UV and ${ }^{1} \mathrm{H}$ NMR data. The reactivity ratio of monomers was obtained by Fineman-Ross and Kelen-Tudos method. Molecular weight was determined by gel permeation chromatography. The monomer and polymers were characterized from their IR data. The results of thermal analysis on polymers are also included in this paper. Homo and copolymers were also tested for their antimicrobial properties against microorganisms such as bacteria (Bacillus subtilis, Escherichia coli and Staphylococcus citreus), fungi (Aspergillus niger, Sporotichum pulverulentum and Trichoderma ligno-

${ }^{\dagger}$ To whom correspondence should be addressed (Tel: +91-2692-226855, E-mail: mituldolia@yahoo.co.in). 
rum) and yeast (Candida utilis, Saccharomyces cerevisiae and Pichia stipitis).

\section{EXPERIMENTAL}

\section{Materials}

4-chloro-3-methyl phenol and methyl methacrylate (S.D. fine chemicals), 2,2'-azobisisobutyronitrile (AIBN, Aldrich), methacrylic acid and benzoyl chloride (chiti chem.) have been used without any further purification. Solvents were purified by fractional distillation.

\section{Synthesis of Methacryloyl Chloride}

Methacryloyl chloride was prepared following the standard procedure given by Stempel. ${ }^{18}$

\section{Synthesis of 4-Chloro-3-methyl Phenyl Methacrylate (CMPM)}

The esterification was performed with methacryloyl chloride and 4-chloro-3-methyl phenol (CMP). Absolute alcohol $(400 \mathrm{~mL})$ and $\mathrm{NaOH}(0.2 \mathrm{~mol}, 8.0 \mathrm{~g})$ were added to a three necked flask, equipped with a stirrer, condenser and thermometer. The flask was placed in a water bath. The contents of the flask were stirred until all the $\mathrm{NaOH}$ dissolved. CMP $(0.2 \mathrm{~mol}, 42.1 \mathrm{~g})$ was added to this. The reaction mixture was heated to $60^{\circ} \mathrm{C}$ for $30 \mathrm{~min}$ with stirring, cooled to room temperature and then to $0-5^{\circ} \mathrm{C}$ by ice. Freshly prepared methacryloyl chloride $(0.21 \mathrm{~mol}, 20.5 \mathrm{~mL})$ was added drop wise within $60 \mathrm{~min}$ to the cooled reaction mixture. The reaction temperature $\left(0-5^{\circ} \mathrm{C}\right)$ was maintained through out the addition. It was then stirred for $90 \mathrm{~min}$ and poured into crushed ice-water mixture, where a light yellow color liquid product settled down. That was extracted with ether. The lower aqueous layer is separated. The remaining solution is transferred to a petry dish to allow evaporation of ether at room temperature and then dried over anhydrous calcium chloride in vacuum desicator. The boiling point of this monomer was found to be $230^{\circ} \mathrm{C}$. Yield $75 \%$.

\section{Characterization of Monomers CMPM}

The monomer was characterized by FTIR and ${ }^{1} \mathrm{H}$ NMR spectroscopy. IR spectra of monomer was recorded using NICOLET 400 D FT IR spectrophotometer. ${ }^{1} \mathrm{H}$ NMR spectra of monomer was recorded on HITACHI-R-1500 FT NMR spectrophotometer (60 $\mathrm{MHz}$ ) using $\mathrm{CDCl}_{3}$ as solvent and tetramethylsilane as an internal standard.

\section{IR Data of Monomer CMPM}

The IR spectrum of monomer CMPM is shown in Figure 2a. The important absorptions in $\mathrm{cm}^{-1}$ are:
$2925\left(v_{-\mathrm{CH}_{3}}\right), 1743\left(v_{\mathrm{C}=\mathrm{O}}\right), 1642\left(v_{\mathrm{C}=\mathrm{C}}\right), 1232$ (asymmetric $v_{\mathrm{C}-\mathrm{O}-\mathrm{C}}$ ) and 1160 (symmetric $v_{\mathrm{C}-\mathrm{O}-\mathrm{C}}$ ), 980 ( $-\mathrm{CH}$ bending mode of vinyl group), 720 (rocking mode of vinyl group), $670\left(v_{\mathrm{C}-\mathrm{Cl}}\right), 1590$ and 1488 (bands due to phenyl ring).

\section{${ }^{1} \mathrm{H} \mathrm{NMR}(\delta \mathrm{ppm})(60 \mathrm{MHz})$ Data of Monomer CMPM}

The NMR spectrum of CMPM is shown in Figure $2 b$. The resonances are:

${ }^{1} \mathrm{H}$ NMR $(\delta \mathrm{ppm})(60 \mathrm{MHz}): 2.275$ (6H) (methyl protons), $6.494(1 \mathrm{H})$ and $6.533(1 \mathrm{H})$ (non-equivalent methylene protons), 7.080-7.217 (3H) (aromatic protons).

\section{Copolymerization}

Copolymers of CMPM with MMA having different feed composition were synthesized by free radical polymerization in toluene using AIBN as free radical initiator. The feed composition of both the monomer and comonomer is given in Table I. Appropriate quantities of monomer, comonomer, toluene $(10 \mathrm{~mL})$, and AIBN ( $0.5 \%$ of total monomers) were mixed in a round bottom flask equipped with mechanical stirrer and reflux condenser. The reaction mixture was heated to $70^{\circ} \mathrm{C}$ for $5 \mathrm{~h}$ with stirring. It was then cooled to room temperature and the resulting polymer solution was slowly poured in a large volume of methanol with stirring, when the polymer precipitated out. It was then filtered and washed with methanol. Solid polymers were purified by repeated precipitation by methanol from solution in DMF and finally dried. Reaction scheme (Figure 1) shows the reaction leading to the formation of homopolymer as well as copolymers of CMPM with MMA. The yield of copolymers varies from 80 to $89 \%$.

\section{Characterization of Polymers}

Infrared spectra of solid samples in $\mathrm{KBr}$ pellets were recorded with a NICOLET-400 D FTIR spectrophotometer. Shimadzu-160-A recording UV-vis spectrophotometer was used to determine copolymer composition and reactivity ratios. HITACHI-R-1500 FT NMR spectrophotometer $(60 \mathrm{MHz})$ was also used to determine copolymer composition. Molecular weights of the polymers were obtained by gel permeation chromatography (Waters $600 \mathrm{E}$ ) equipped with a 410-RI detectors calibrated with polystyrene standards. Thermogravimetic analysis was performed with Du Pont-951 thermal analyzer at a heating rate of $10^{\circ} \mathrm{C} / \mathrm{min}$ in nitrogen atmosphere. Differential thermal analysis (DTA) traces were obtained with Du Pont-9900 differential thermal analyzer at a heating rate of $10^{\circ} \mathrm{C} / \mathrm{min}$ in nitrogen atmosphere. A heating rate of $10^{\circ} \mathrm{C} / \mathrm{min}$ and a sample size of $10 \pm 1 \mathrm{mg}$ were used in each experiment. Intrinsic viscosity 
Table I. Copolymer composition and reactivity ratios of copolymers of CMPM and MMA

\begin{tabular}{|c|c|c|c|c|c|c|c|c|c|c|c|c|c|c|}
\hline \multirow{2}{*}{$\begin{array}{c}\text { Sample } \\
\text { code } \\
\text { no. }\end{array}$} & \multicolumn{2}{|c|}{$\begin{array}{c}\text { Monomer feed } \\
\text { composition }\end{array}$} & \multirow[b]{2}{*}{$\begin{array}{c}\text { Conversion } \\
(\%)\end{array}$} & \multirow{2}{*}{$\begin{array}{c}\text { Composition } \\
\text { of CMPM } \\
\text { in the copolymer } \\
{\left[\mathrm{m}_{1}\right]}\end{array}$} & \multirow[b]{2}{*}{$\mathrm{F}=\frac{\mathrm{M}_{1}}{\mathrm{M}_{2}}$} & \multirow[b]{2}{*}{$\mathrm{f}=\frac{\mathrm{m}_{1}}{\mathrm{~m}_{2}}$} & \multirow[b]{2}{*}{$H=\frac{F^{2}}{f}$} & \multirow[b]{2}{*}{$G=\frac{F(f-1)}{f}$} & \multirow[b]{2}{*}{$\eta=$} & \multirow[b]{2}{*}{$\xi=\frac{\mathrm{H}}{\alpha+\mathrm{H}}$} & \multicolumn{4}{|c|}{ Reactivity ratio } \\
\hline & $\begin{array}{c}\text { CMPM } \\
{\left[\mathrm{M}_{1}\right]} \\
(\text { mole })\end{array}$ & $\begin{array}{c}\text { MMA } \\
{\left[\mathrm{M}_{2}\right]} \\
(\text { mole })\end{array}$ & & & & & & & & & $\mathrm{F}-$ & $\mathrm{R}$ & $\mathrm{K}$ & $-\mathrm{T}$ \\
\hline M-1 & 1.0 & - & - & - & & & & & & & $\mathrm{r}_{1}$ & $\mathrm{r}_{2}$ & $\mathrm{r}_{1}$ & $\mathrm{r}_{2}$ \\
\hline M-2 & 0.2 & 0.8 & 8.72 & $(0.246)^{*}, 0.225$ & 0.25 & 0.290 & 0.216 & -0.612 & -0.493 & 0.174 & & & & \\
\hline M-3 & 0.4 & 0.6 & 9.12 & $(0.375)^{*}, 0.389$ & 0.67 & 0.636 & 0.706 & -0.383 & -0.221 & 0.408 & & & & \\
\hline M-4 & 0.5 & 0.5 & 8.83 & $(0.483)^{*}, 0.468$ & 1.0 & 0.88 & 1.136 & -0.136 & -0.063 & 0.526 & 0.75 & 0.88 & 0.70 & 0.82 \\
\hline M-5 & 0.6 & 0.4 & 7.86 & $(0.571)^{*}, 0.573$ & 1.5 & 1.342 & 1.677 & 0.382 & 0.142 & 0.621 & & & & \\
\hline M-6 & 0.8 & 0.2 & 8.42 & $(0.775)^{*}, 0.767$ & 4.0 & 3.292 & 4.860 & 2.785 & 0.473 & 0.826 & & & & \\
\hline M-7 & - & 1.0 & - & - & & & & & & & & & & \\
\hline
\end{tabular}

$\alpha=\left(\mathrm{H}_{\max } * \mathrm{H}_{\min }\right)^{1 / 2}$

$*$ Value in parenthesis are obtained from ${ }^{1} \mathrm{H}$ NMR data.

(a)<smiles>C=C(C)C(=O)Oc1ccc(Cl)c(C)c1</smiles>

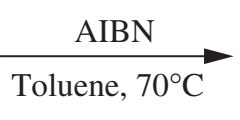<smiles>Cc1cc(OC(=O)C(C)(C)CC(C)(C)C)ccc1Cl</smiles>

(b)<smiles>C=C(C)C(=O)OC</smiles>

(c)<smiles>C=C(C)C(=O)Oc1ccc(Cl)c(C)c1</smiles>

Figure 1. Synthesis scheme of (a) Homo CMPM (b) Homo MMA (c) Poly(CMPM-co-MMA).

$(\eta)$ of the copolymers were measured in toluene at $25 \pm 0.1^{\circ} \mathrm{C}$ using an Ubbelhode suspended level viscometer.

\section{Antimicrobial Activity}

The homo and copolymers prepared were tested for their antimicrobial activity against bacterial strain 

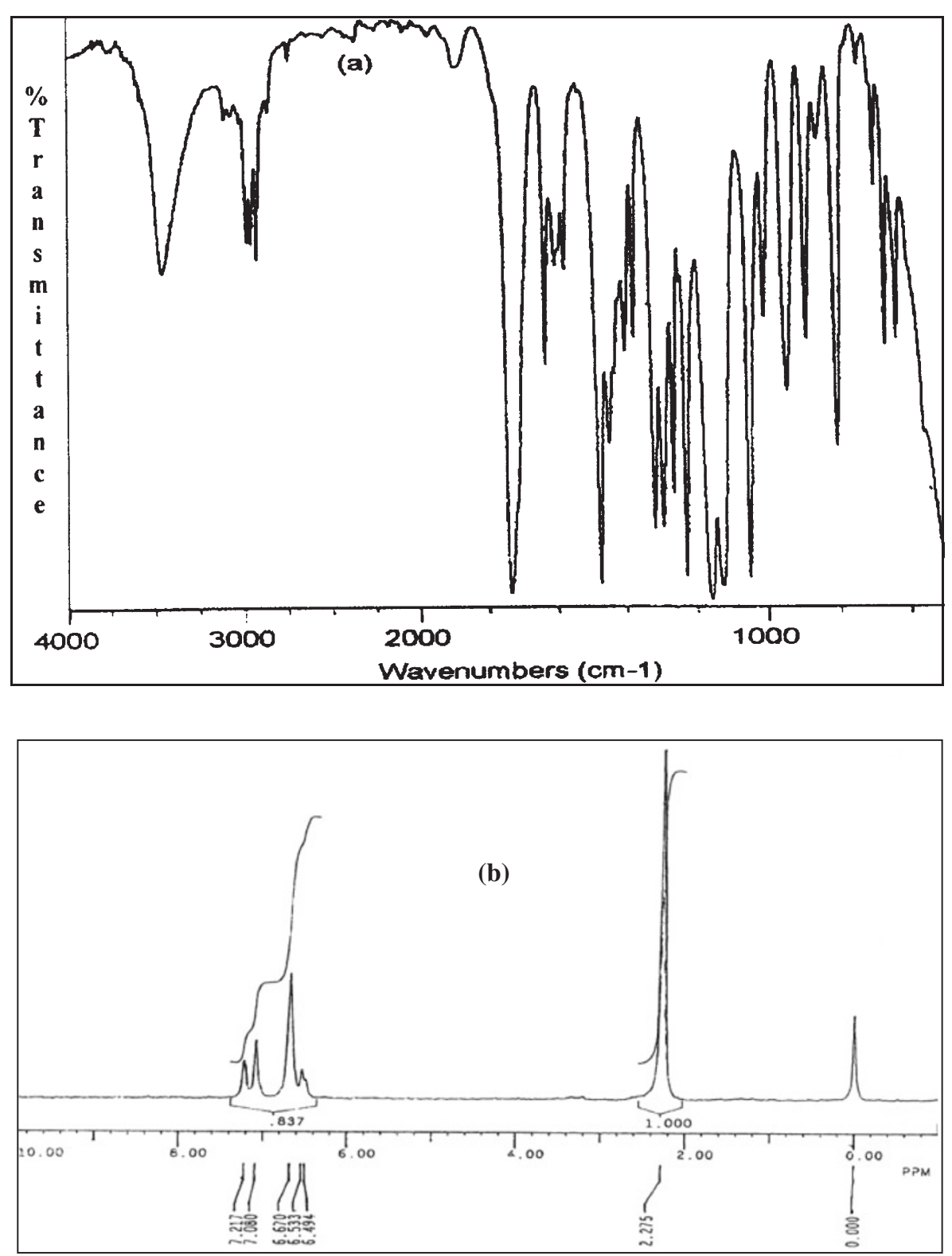

Figure 2. (a) IR spectrum of monomer CMPM (b) ${ }^{1} \mathrm{H}$ NMR spectrum of monomer CMPM.

(Bacillus subtilis, Escherichia coli and Staphylococcus citreus), fungal strain (Aspergillus niger, Sporotichum pulverulentum and Trichoderma lignorum) and yeast strain (Candida utilis, Saccharomyces cerevisiae and Pichia stipitis). These microorganisms were grown in Nutrient broth (N-broth), Subourand's dextrose broth and yeast extract peptone dextrose (YEPD) media with or without indicated polymer respectively. The content of the flasks were incubated in a shaker at room temperature. At specific time intervals (20$48 \mathrm{~h}$ ), the optical density was measured at $660 \mathrm{~nm}$ for bacterial and yeast cultures. The fungal cultures were harvested after $48 \mathrm{~h}$ and the dry cell mass was determined gravimetrically. The details of experimental procedure have been reported elsewhere. ${ }^{17,19}$

\section{RESULTS AND DISCUSSION}

Five copolymers of CMPM with MMA were synthesized by taking different mole fraction of the monomers in the feed ranging from 0.2 to 0.8 (Table I). In order to satisfy the differential copolymerization equation, the reaction time was so selected as to have less than $10 \mathrm{wt} \%$ conversion. The copolymers are characterized by IR technique and the results are discussed here.

The IR spectra of copolymers shown in Figure 3 exhibit expected characteristic group frequencies. The medium bands in the range of 2928 and 2855 $\mathrm{cm}^{-1}$ may be due to $\mathrm{C}-\mathrm{H}$ stretching vibrations of methyl and methylene groups respectively. Bands at 


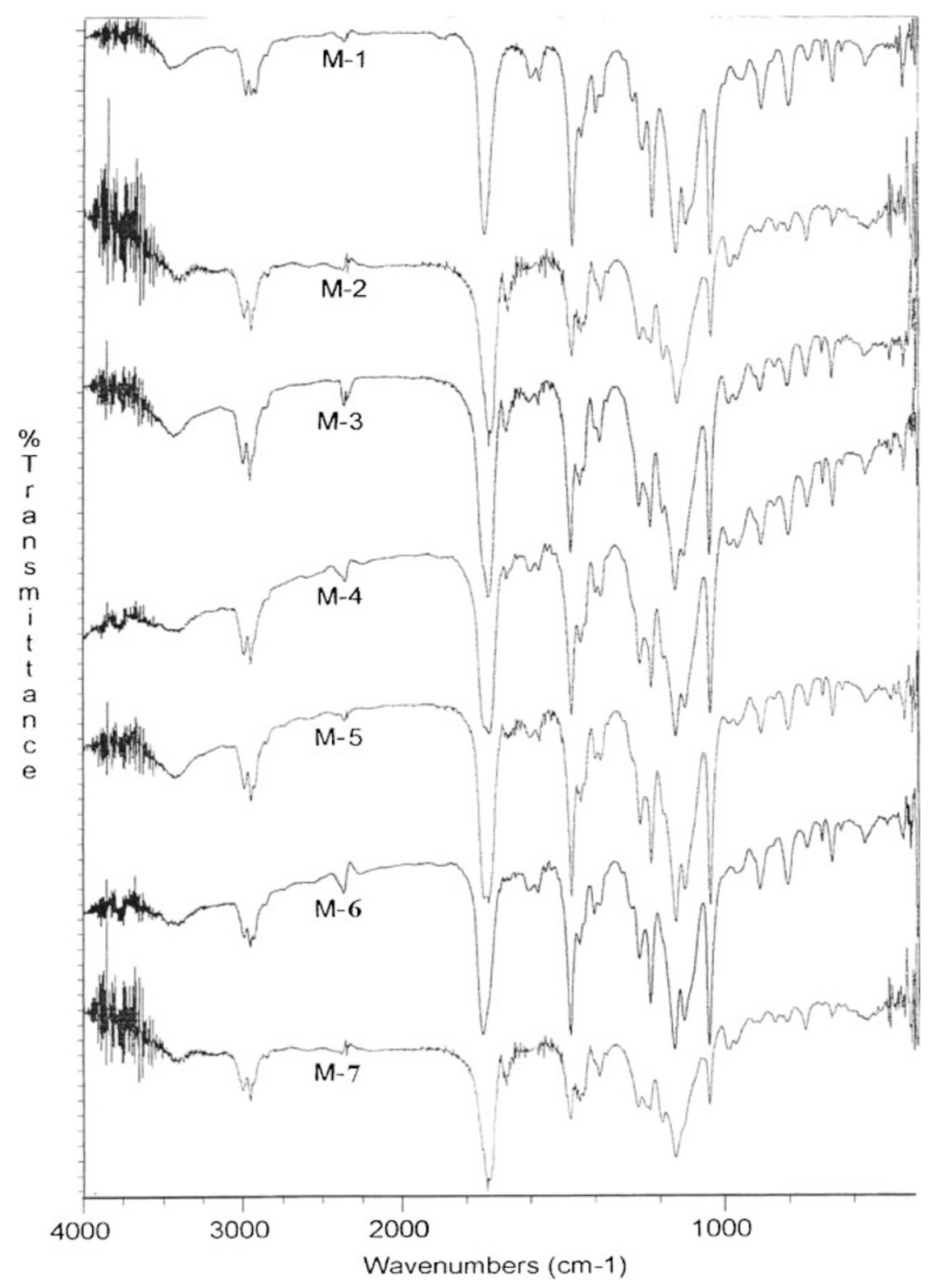

Figure 3. IR Spectra for copolymers of CMPM with MMA.

1410 and $1456 \mathrm{~cm}^{-1}$ could be assigned respectively to symmetric and asymmetric methyl group bending vibration. ${ }^{20}$ The latter could be due $\mathrm{CH}_{2}$ bending also. Interestingly as the CMPM content increases in the copolymer, the intensity of absorption at 1770 (due to $\mathrm{C}=\mathrm{O}$ stretching vibration in phenyl ester) also increases and the intensity of 1730 (due to $\mathrm{C}=\mathrm{O}$ stretching vibration in MMA ester) decreases as MMA content decreases. The aromatic ring breathing vibrations in these polymers are assigned at approximately 1600 and $1500 \mathrm{~cm}^{-1}$. The $\mathrm{C}-\mathrm{O}-\mathrm{C}$ stretching vibrations are attributed to the strong absorption in the region 1300$1250 \mathrm{~cm}^{-1}$ and the sharp band at $670 \mathrm{~cm}^{-1}$ is assigned to $\mathrm{C}-\mathrm{Cl}$ streching. ${ }^{21}$ The absence of absorptions at 980 and $1642 \mathrm{~cm}^{-1}$ in the polymers indicates that the vinyl group has taken part in polymerization.

\section{Copolymer Composition and Reactivity Ratios}

The average composition of each copolymer sample was determined from the corresponding UV-spectrum. The assignment of the absorption in the UVspectrum allows accurate determination of the content of each kind of monomeric unit incorporated into the copolymer chains. The $\lambda_{\max }$ for poly(CMPM) was found at $270 \mathrm{~nm}$, while that of poly(MMA) was observed at $250 \mathrm{~nm}$. The UV-spectra of different composition of copolymers are shown in Figure $4 \mathrm{a}$ and that of poly(MMA) is shown in Figure 4b. The composition of the copolymers of CMPM and MMA was obtained from the UV-spectral data. The reactivity ratios of CMPM and MMA were obtained from FinemanRoss method ${ }^{22}$ and are shown in Table I. The reactivity ratios were also obtained by Kelen-Tudos ${ }^{23,24}$ 


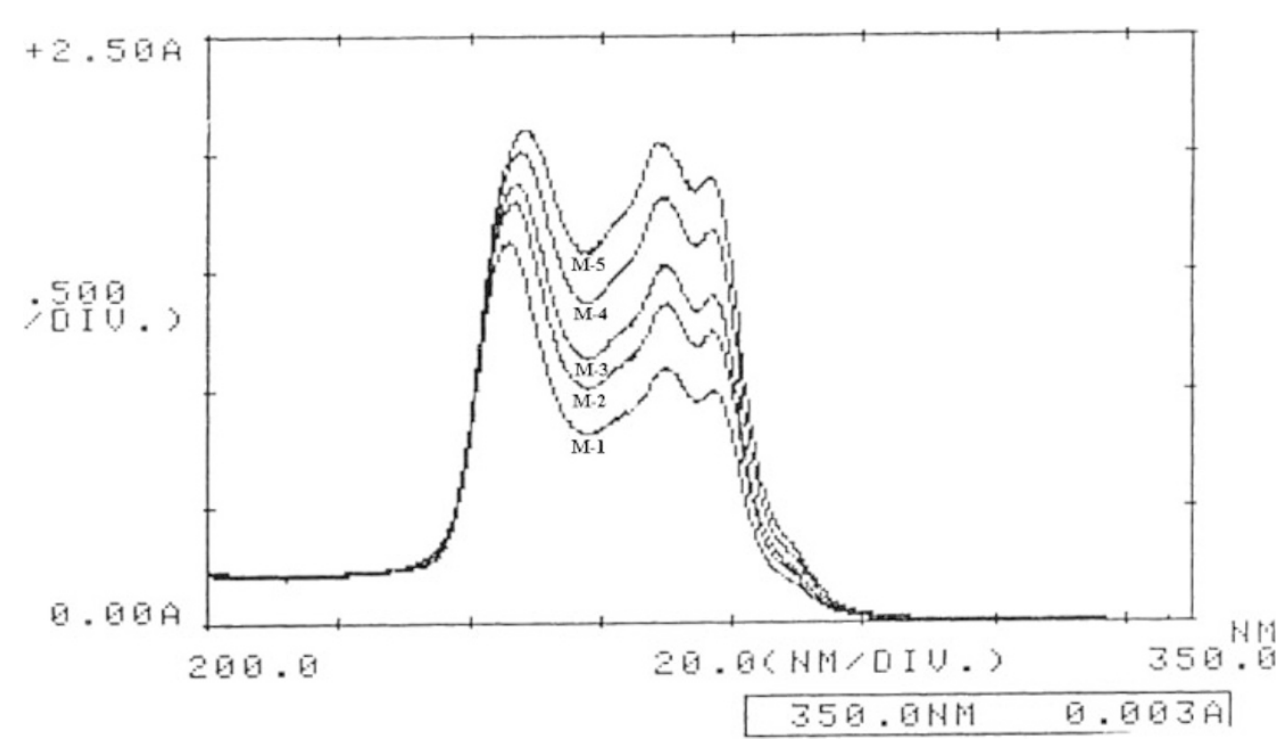

(a)

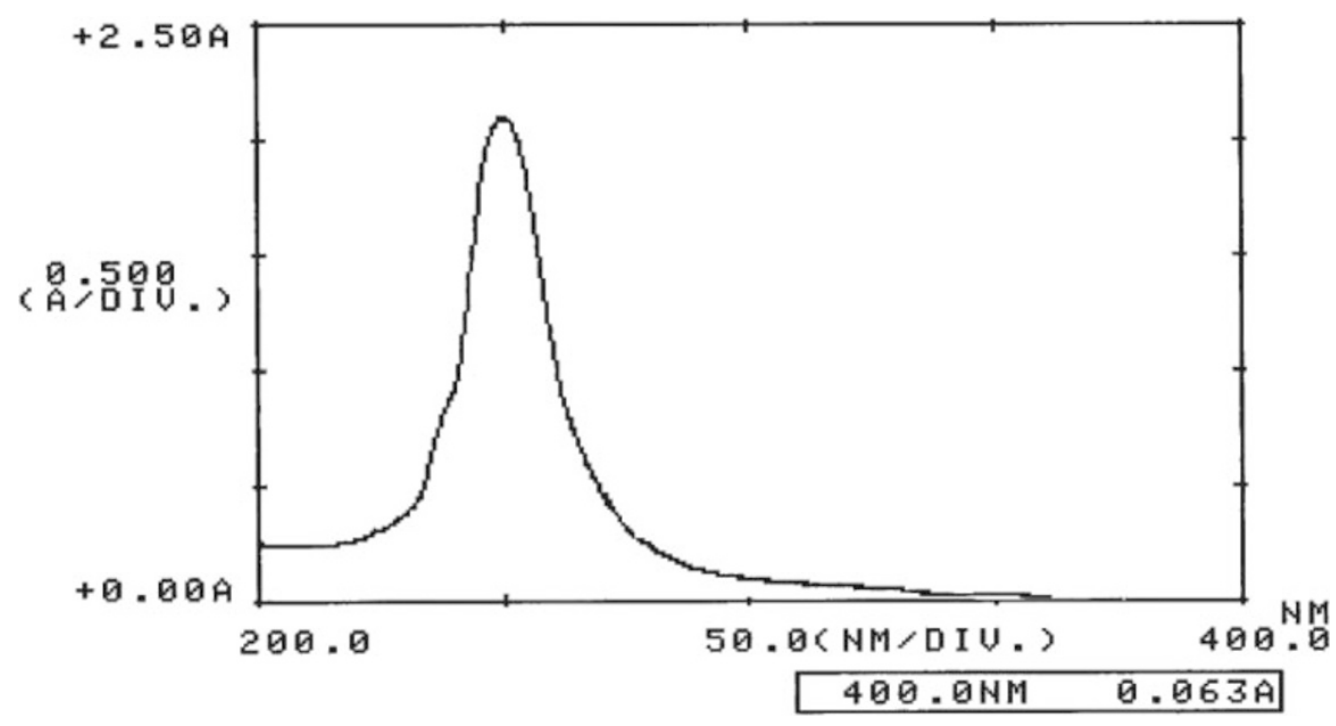

(b)

Figure 4. (a) UV Spectra for copolymers of CMPM with MMA. (b) UV Spectrum of poly(MMA).

method. These values are also shown in Table I. The reactivity ratios obtained by these two methods agree well. The reaction time was selected in such a way that conversion was less than $10 \%$ in weight. This was done to satisfy the differential copolymerization equation for calculation of reactivity ratio. ${ }^{22}$ A plot of $\mathrm{G} v s$. $\mathrm{H}$ in $\mathrm{F}-\mathrm{R}$ method was a straight line as shown in Figure 6a.

The intercept at $\mathrm{Y}$-axis gives the value of $-\mathrm{r}_{2}$ and the slop gives the value of $r_{1}$. Similarly in K-T method, plot of $\eta$ against $\xi$ gives a straight line shown in Figure $6 \mathrm{~b}$ which when extrapolated to $\xi=0$ and $\xi=$ 1 gives $-r_{2} / \alpha$ and $r_{1}$ respectively. When $r_{1}$ and $r_{2}$ are less than one, the system gives rise to azeotropic polymerization at a particular composition of the monomer, which is calculated using the equation ${ }^{25}$

$$
\begin{aligned}
\mathrm{N}_{1} & =\frac{\left(1-\mathrm{r}_{2}\right)}{\left(2-\mathrm{r}_{1}-\mathrm{r}_{2}\right)} \\
& =0.324 \text { (by F-R method) }
\end{aligned}
$$

Where $\mathrm{N}_{1}$ is the mole fraction of CMPM in the feed. When the mole fraction of the monomer CMPM in the feed is 0.324 the copolymer formed will have the same composition as that in the feed. When the mole fraction of CMPM in the feed is less than 0.324 the copolymer is relatively richer in this monomeric unit than the feed. When the mole fraction of the monomeric CMPM in the feed is above 0.324 the copolymer is relatively richer in MMA monomeric units.

The composition of each of copolymer samples was determined from the corresponding ${ }^{1} \mathrm{H}$ NMR spectra also. The ${ }^{1} \mathrm{H}$ NMR spectra of the copolymers are giv- 


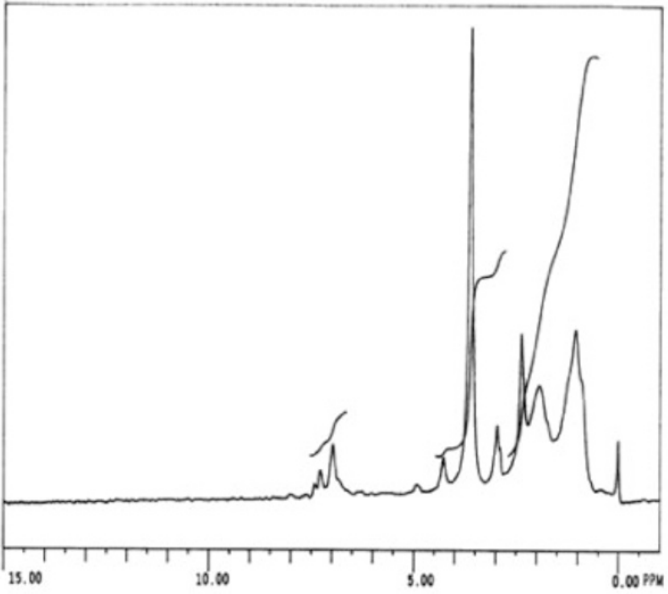

$(0.2: 0.8)$

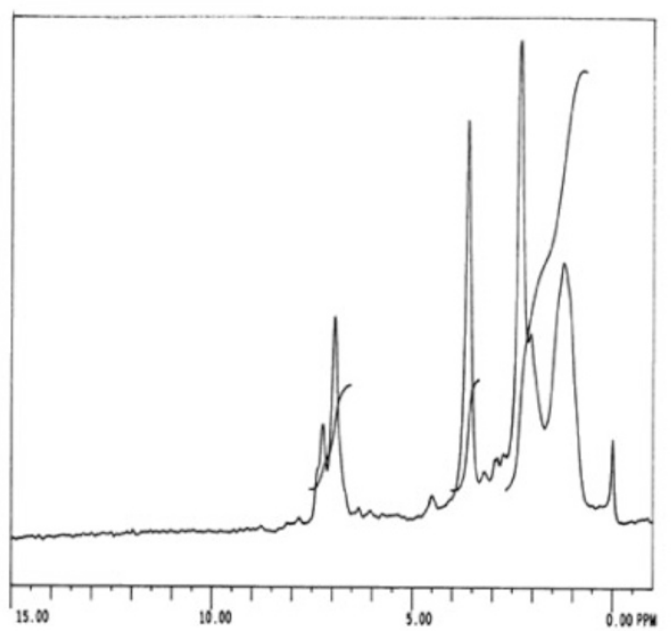

$(0.5: 0.5)$

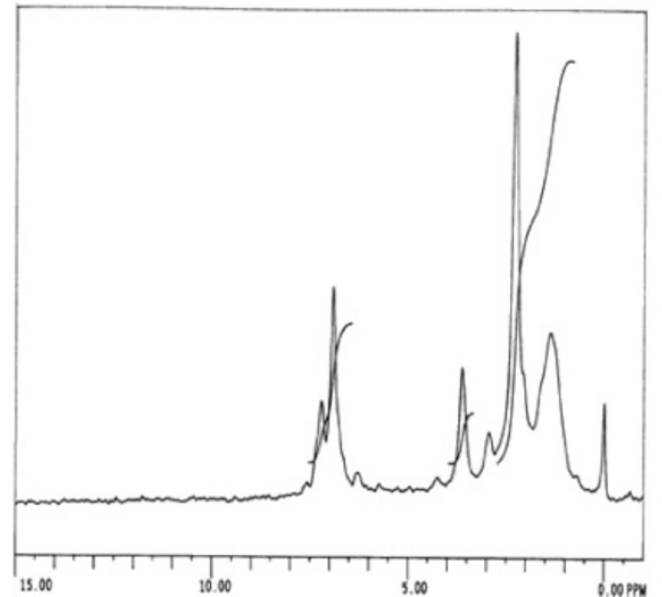

$(0.8: 0.2)$

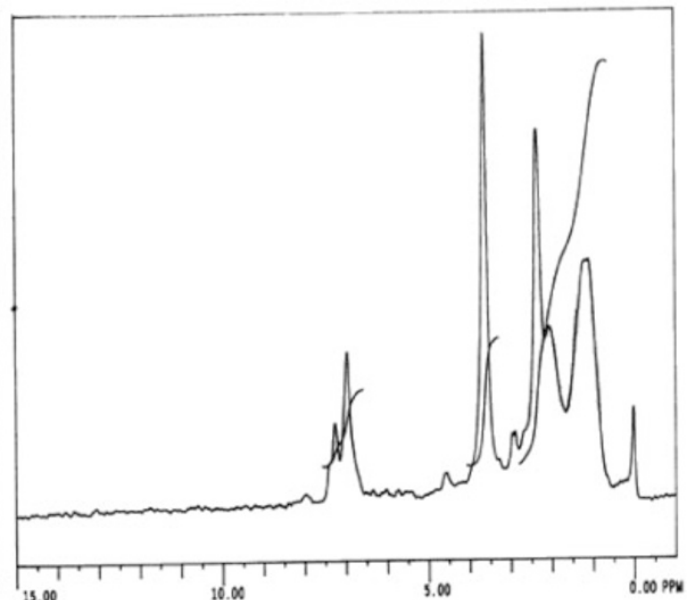

$(0.4: 0.6)$

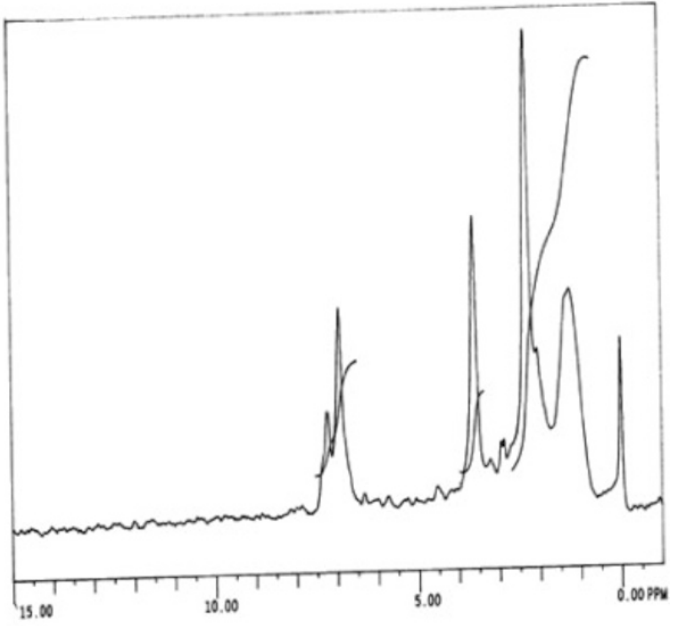

$(0.6: 0.4)$

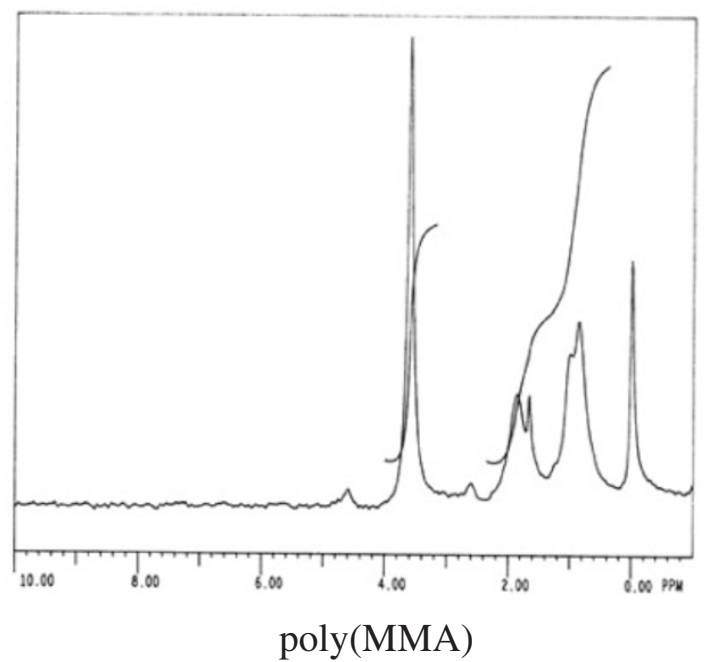

Figure 5. ${ }^{1} \mathrm{H}$ NMR Spectra of poly(MMA) and copolymers of CMPM with MMA.

en in Figure 5. The peaks around 6.9 to $7.2 \mathrm{ppm}$ are due to aromatic protons. The peak at $3.61 \mathrm{ppm}$ is assigned to $-\mathrm{OCH}_{3}$ group. The remaining resonances are due to other aliphatic protons. The composition of the copolymers was calculated by comparing the intensities of the aromatic protons and the total ali- phatic protons of the copolymer.

The copolymer composition was obtained in the following way. Let $\mathrm{m}_{1}$ be the mole fraction of CMPM and $\mathrm{m}_{2}$ be the mole fraction of MMA. CMPM contains 3 aromatic protons and 8 aliphatic protons. MMA unit has 8 aliphatic protons. 


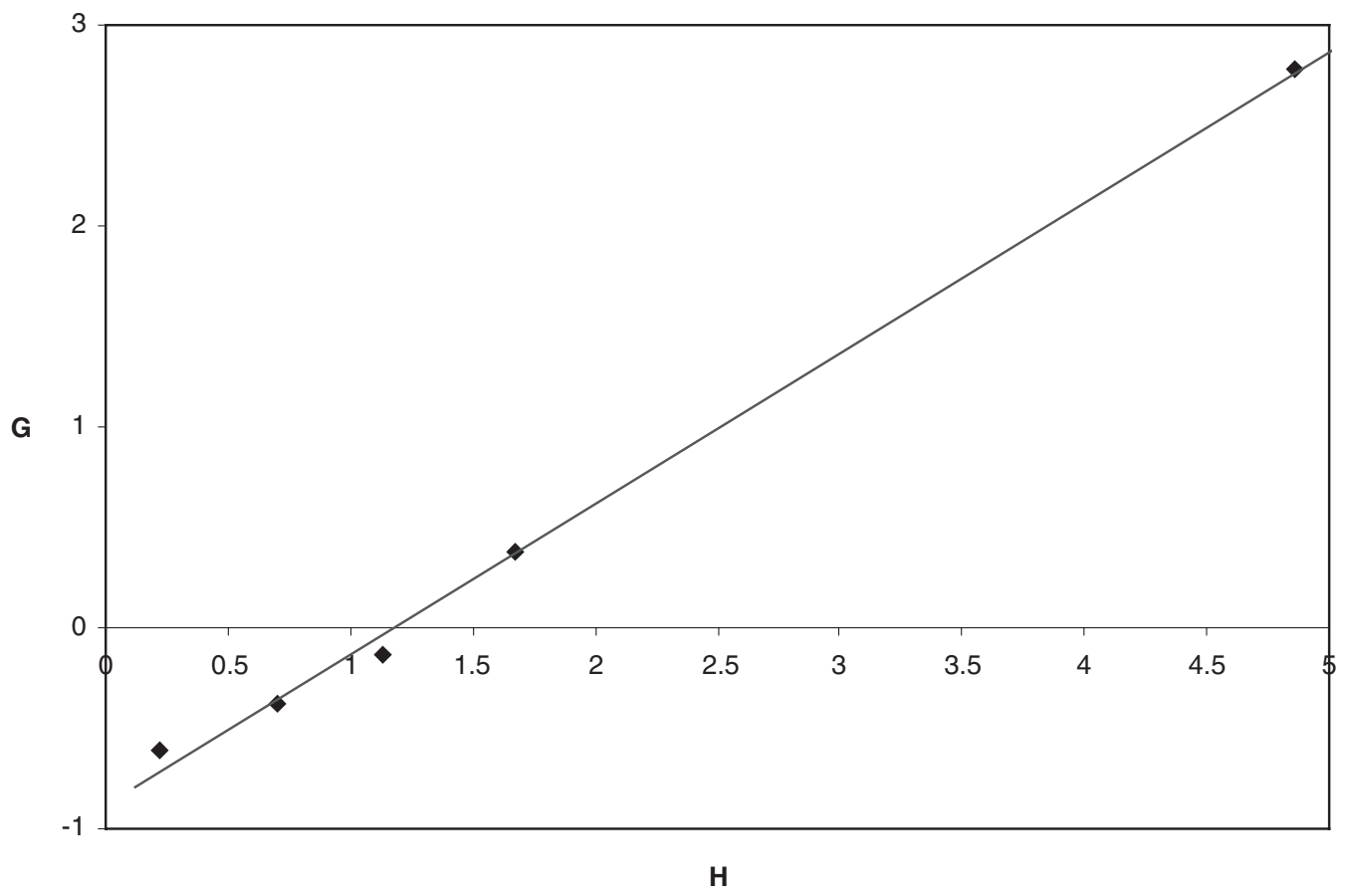

(a)

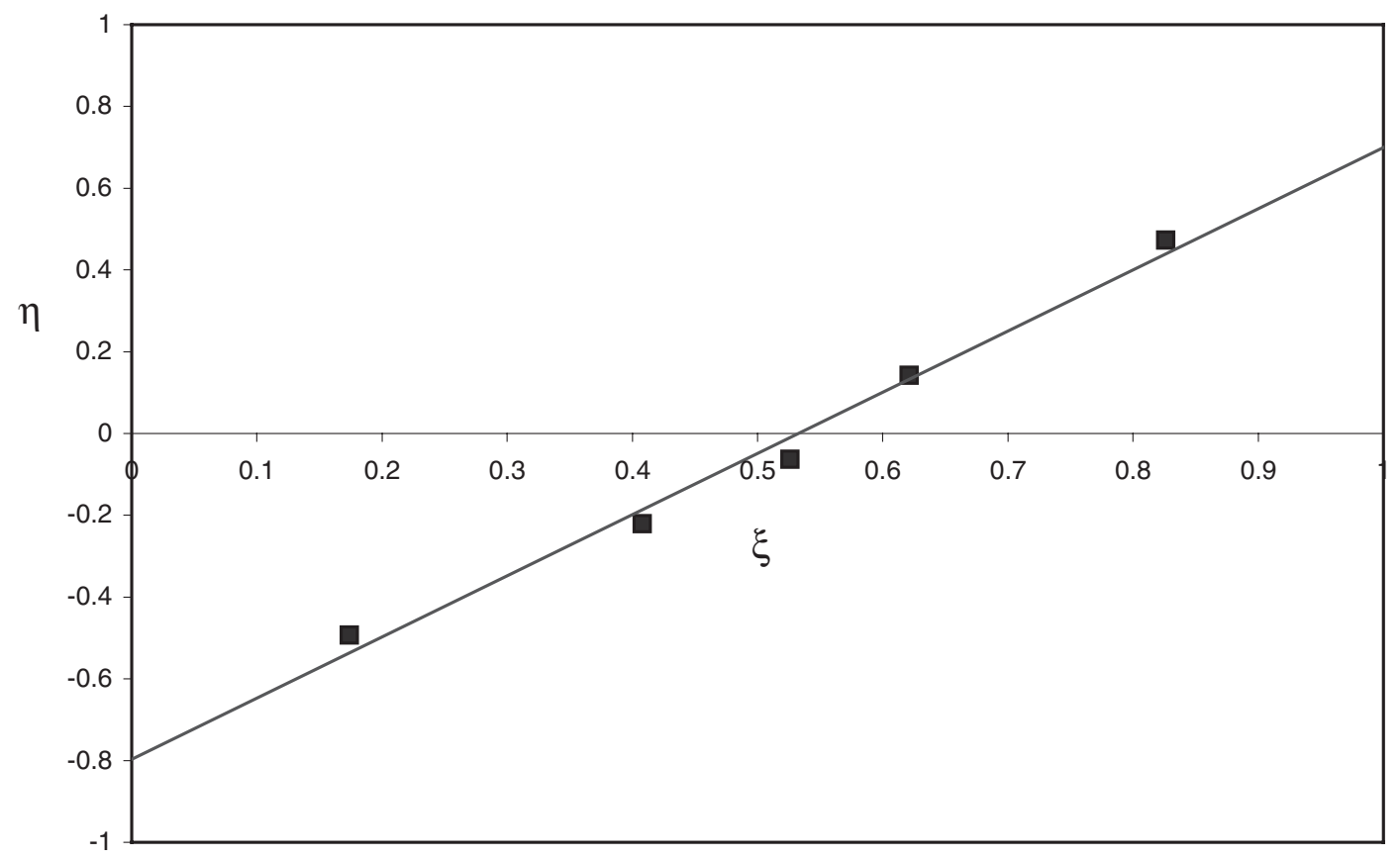

(b)

Figure 6. (a) F-R plot for poly(CMPM-co-MMA). (b) K-T plot for poly(CMPM-co-MMA).

A parameter $\mathrm{K}$ is defined as

$$
\begin{aligned}
\mathrm{K} & =\frac{\text { Intensities of aromatic protons }}{\text { Intensities of aliphatic protons }} \\
& =\frac{3 \mathrm{~m}_{1}}{8 \mathrm{~m}_{1}+8 \mathrm{~m}_{2}}
\end{aligned}
$$

It is also know that,

$$
\mathrm{m}_{1}+\mathrm{m}_{2}=1
$$

Combining eqs (2) and (3)

$$
\mathrm{m}_{1}=\frac{8 \mathrm{~K}}{3}
$$

The results of these calculations are shown in Table I. The compositions obtained from ${ }^{1} \mathrm{H}$ NMR and UV data compare well. 
Table II. Average molecular weights by GPC data for the copolymers of CMPM with MMA

\begin{tabular}{ccccc}
\hline $\begin{array}{c}\text { Sample } \\
\text { code } \\
\text { no. }\end{array}$ & $M_{\mathrm{n}}$ & $M_{\mathrm{w}}$ & $\begin{array}{c}\text { Polydispersity } \\
\left(M_{\mathrm{w}} / M_{\mathrm{n}}\right)\end{array}$ & $\begin{array}{c}\text { Intrinsic } \\
\text { viscosity } \\
{[\eta] \mathrm{dl} \cdot \mathrm{g}^{-1}}\end{array}$ \\
\hline M-1 & 44011 & 67821 & 1.541 & 0.210 \\
M-2 & 35421 & 51892 & 1.465 & 0.178 \\
M-4 & 38945 & 57833 & 1.485 & 0.186 \\
M-6 & 44487 & 69310 & 1.558 & 0.196 \\
M-7 & 45609 & 74069 & 1.624 & 0.230 \\
\hline
\end{tabular}

\section{Molecular Weight and Viscosity Measurement}

The number and weight average molecular weight of poly(CMPM), poly(MMA) and five samples of copolymers were obtained using gel permeation chromatographic technique. The polydispersity index of homo and copolymers varied in the range of 1.4651.624. The intrinsic viscosities $(\eta)$ were obtained by extrapolating $\eta_{\mathrm{spC}}{ }^{-1} v s$. C to zero concentration. Molecular weights and viscosities are presented in Table II.

\section{Thermal Analysis}

The thermal stability of the polymers were identified by estimating the percentage weight loss of the polymer on thermal decomposition. The decomposition temperature of the copolymers depends on the composition of the constituent monomeric units in the copolymer. The results of TGA analysis of poly(CMPM), poly(CMPM-co-MMA) (20:80, 50:50, 80:20 monomer feed ratio) and poly(MMA) are presented in Table III. The data clearly indicate that all copolymers of CMPM undergo two step decomposition while homo polymers of both the monomers show one step decomposition in the temperature range of $210-472{ }^{\circ} \mathrm{C}$. The activation energy $\left(E_{\mathrm{A}}\right)$ calculated
Table IV. DTA data for poly(CMPM), poly(MMA) and their copolymers

\begin{tabular}{cccccc}
\hline $\begin{array}{c}\text { Sample } \\
\text { code } \\
\text { no. }\end{array}$ & $\begin{array}{c}T_{1}{ }^{\mathrm{a}} \\
\left({ }^{\circ} \mathrm{C}\right)\end{array}$ & $\begin{array}{c}T_{2}{ }^{\mathrm{b}} \\
\left({ }^{\circ} \mathrm{C}\right)\end{array}$ & $\begin{array}{c}T_{\mathrm{P}}{ }^{\mathrm{c}} \\
\left({ }^{\circ} \mathrm{C}\right)\end{array}$ & $\begin{array}{c}\text { Activation } \\
\text { energy } \\
\left(E_{\mathrm{A}}\right)\end{array}$ & $\begin{array}{c}\text { Reaction } \\
\text { order } \\
\left(\mathrm{K} \cdot \mathrm{J} \cdot \mathrm{mol}^{-1}\right)\end{array}$ \\
\hline M-1 & 400 & 540 & 445 & 103 & 1 \\
\hline M-2 & 295 & 418 & 340 & 110 & 1 \\
& 418 & 497 & 442 & 113 & 1 \\
\hline M-4 & 290 & 381 & 336 & 107 & 1 \\
& 381 & 490 & 440 & 112 & 1 \\
\hline M-6 & 299 & 380 & 335 & 105 & 1 \\
& 380 & 488 & 439 & 107 & 1 \\
\hline M-7 & 398 & 520 & 438 & 102 & 1 \\
\hline
\end{tabular}

${ }^{a}$ Staring temperature of DTA. ${ }^{b}$ Ending temperature of DTA trace. ${ }^{c}$ Peak maxima temperature of DTA trace. ${ }^{\mathrm{d}}$ Activation energy by Reich's method.

by Broido's method, ${ }^{26}$ lies in the range of $102-115$ $\mathrm{K} \cdot \mathrm{J} \cdot \mathrm{mol}^{-1}$. The integral procedural decomposition temperature (IPDT) was calculated by Doyle's method. ${ }^{27}$ IPDT expresses the overall thermal stability of the polymer and it varies between $360-394{ }^{\circ} \mathrm{C}$ for these polymers.

DTA data of poly(CMPM), poly(CMPM-co-MMA) (20:80, 50:50, 80:20 monomer feed ratio) and poly(MMA) are presented in Table IV. It is observed that as the CMPM content in the polymer increases, the thermal stability also increases. This may be attributed to the increase in the number of aromatic rings. As expected homopolymer of CMPM has the highest thermal stability here. The activation energy for thermal degradation and reaction order were obtained by Reich's method. ${ }^{28}$ The activation energy for thermal degradation of polymers ranged from 102-113 $\mathrm{K} \cdot \mathrm{J} \cdot \mathrm{mol}^{-1}$.

Table III. TGA data for poly(CMPM), poly(MMA) and their copolymers

\begin{tabular}{|c|c|c|c|c|c|c|c|c|c|}
\hline \multirow[t]{2}{*}{$\begin{array}{l}\text { Sample } \\
\text { code } \\
\text { no. }\end{array}$} & \multicolumn{4}{|c|}{$\begin{array}{c}\% \text { Weight loss at various } \\
\text { temperature } \\
\left({ }^{\circ} \mathrm{C}\right)\end{array}$} & \multirow[t]{2}{*}{$\begin{array}{l}\text { Decomposition } \\
\text { temperature } \\
\text { range } \\
\left({ }^{\circ} \mathrm{C}\right)\end{array}$} & \multirow[t]{2}{*}{$\begin{array}{c}T_{\mathrm{Max}}{ }^{\mathrm{a}} \\
\left({ }^{\circ} \mathrm{C}\right)\end{array}$} & \multirow[t]{2}{*}{$\begin{array}{l}T_{50}{ }^{\mathrm{b}} \\
\left({ }^{\circ} \mathrm{C}\right)\end{array}$} & \multirow[t]{2}{*}{$\begin{array}{c}\text { IPDT }^{\mathrm{c}} \\
\left({ }^{\circ} \mathrm{C}\right)\end{array}$} & \multirow[t]{2}{*}{$\begin{array}{l}\text { Activation } \\
\text { energy }^{\mathrm{d}} \\
\left(E_{\mathrm{A}}\right) \\
\left(\mathrm{K} \cdot \mathrm{J} \cdot \mathrm{mol}^{-1}\right)\end{array}$} \\
\hline & 250 & 350 & 450 & 550 & & & & & \\
\hline M-1 & 0.98 & 7.27 & 87.20 & 89.41 & $270-472$ & 399 & 396 & 394 & 102 \\
\hline \multirow[t]{2}{*}{ M-2 } & 7.28 & 47.55 & 93.95 & 98.88 & $227-330$ & 375 & 360 & 363 & 113 \\
\hline & & & & & $330-443$ & & & & 115 \\
\hline \multirow[t]{2}{*}{ M-4 } & 2.87 & 45.86 & 97.58 & 99.20 & 219-330 & 370 & 359 & 360 & 105 \\
\hline & & & & & $330-439$ & & & & 103 \\
\hline \multirow[t]{2}{*}{ M-6 } & 11.97 & 43.79 & 93.28 & 95.05 & $222-325$ & 369 & 357 & 360 & 105 \\
\hline & & & & & $325-439$ & & & & 103 \\
\hline M-7 & 2.60 & 20.12 & 98.35 & 99.02 & $210-428$ & 390 & 386 & 385 & 101 \\
\hline
\end{tabular}




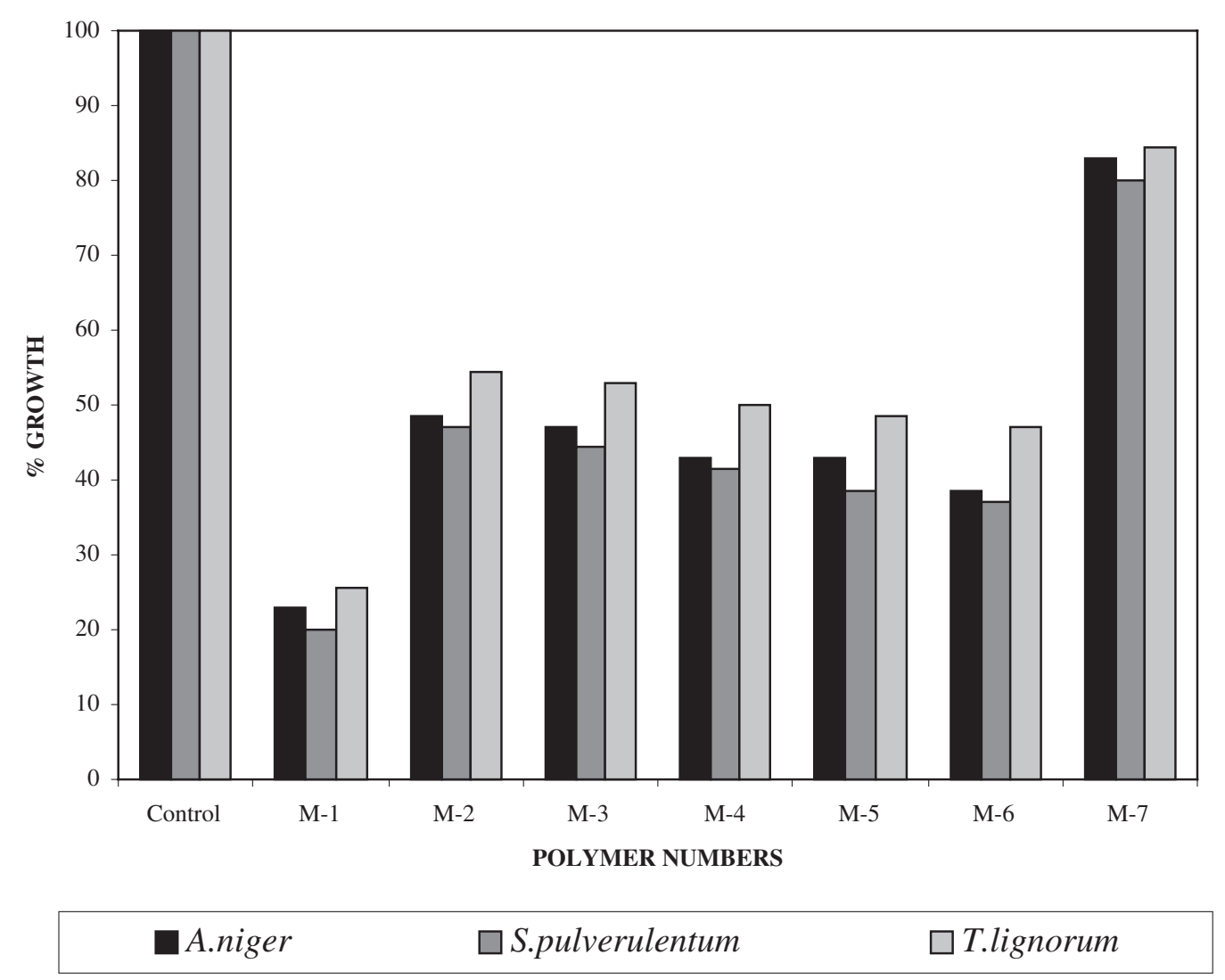

Figure 7. Effect of homo- and copolymers on percentage growth of bacteria.

\section{Antimicrobial Activity}

The antimicrobial activity of homo and copolymers of CMPM and MMA was investigated. The results obtained are presented in Figures 7, 8 and 9. It has been suggested that presence of chlorine in a compound is of prime importance for its antimicrobial activity. ${ }^{29,30}$ All the copolymers systems showed almost similar antimicrobial properties against bacteria, fungi and yeast. Poly(CMPM) allowed about 18-23\% growth of bacteria where as its copolymers favored $35-51 \%$ growth. Poly(CMPM) allowed 20-25\% growth of fungi where as its copolymers favored $37-53 \%$ growth. Yeast however in the presence of poly(CMPM) registered around 21-24\% growth where as $39-55 \%$ growth for yeast was observed in the copolymers. It was observed that copolymers of CMPM and MMA show strong inhibitory effect (Figures 7-9) against tested microorganisms than the homopolymer of MMA. Interestingly the homopolymer of MMA shows antimicrobial property to very less extent. It appears that polymers having no chlorine might also demonstrate antimicrobial activity, although presence of chlorine enhances this activity many fold. It is concluded that as the percentage of CMPM in the copolymers increases, the effectiveness of the copolymers to inhibit the growth of microorganisms increases and as expected the homopolymer of CMPM shows maximum growth inhibition. Although the chlorine content of polymers appeared to be most important for imparting antimicrobial properties, it is to be noted that other moieties also possess antimicrobial activity. The copolymers of CMPM with 8-Quinolinyl methacrylate ${ }^{17}$ are more potent antimicrobial agents than the copolymers of CMPM and MMA. It thus appears that 8Quinoline moiety also might have some role to enhance antimicrobial activity. Such role of other moieties needs to be systematically studied. The study of the mechanism of activity is beyond the scope of the paper. However, we may attempt a tentative mechanism. All the micro-organisms contain $\mathrm{RNH}-\mathrm{CH}_{2}-$ $\mathrm{COOH}$ molecule. The moiety<smiles>COc1ccc(Cl)c(C)c1</smiles>

will possibly react with the amino acid and $\mathrm{HCl}$ will be evolved.

\section{CONCLUSIONS}

New methacrylate based homo and copolymers were synthesized by free radical solution polymerization technique. The monomers and copolymers were 


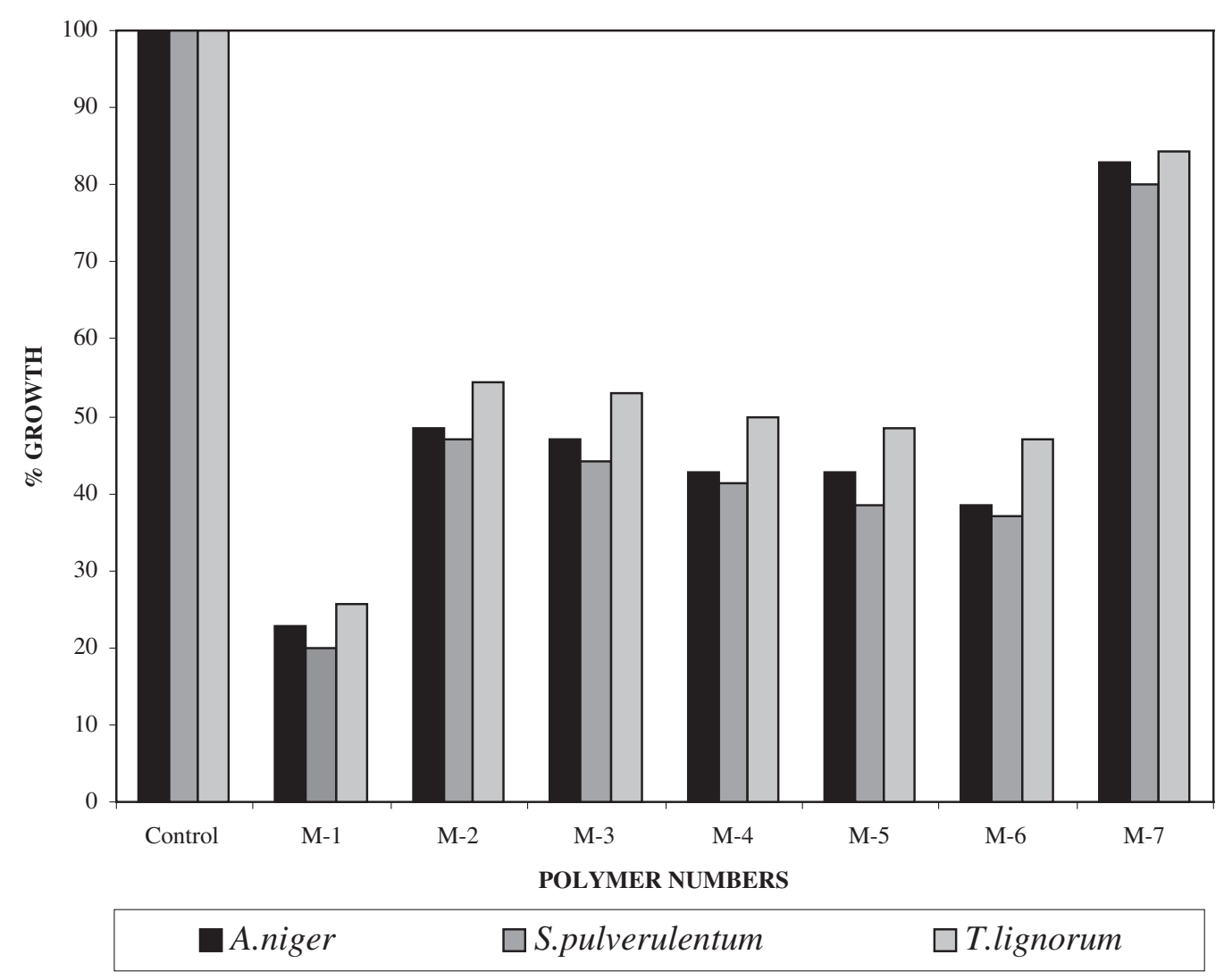

Figure 8. Effect of homo- and copolymers on percentage growth of fungi.

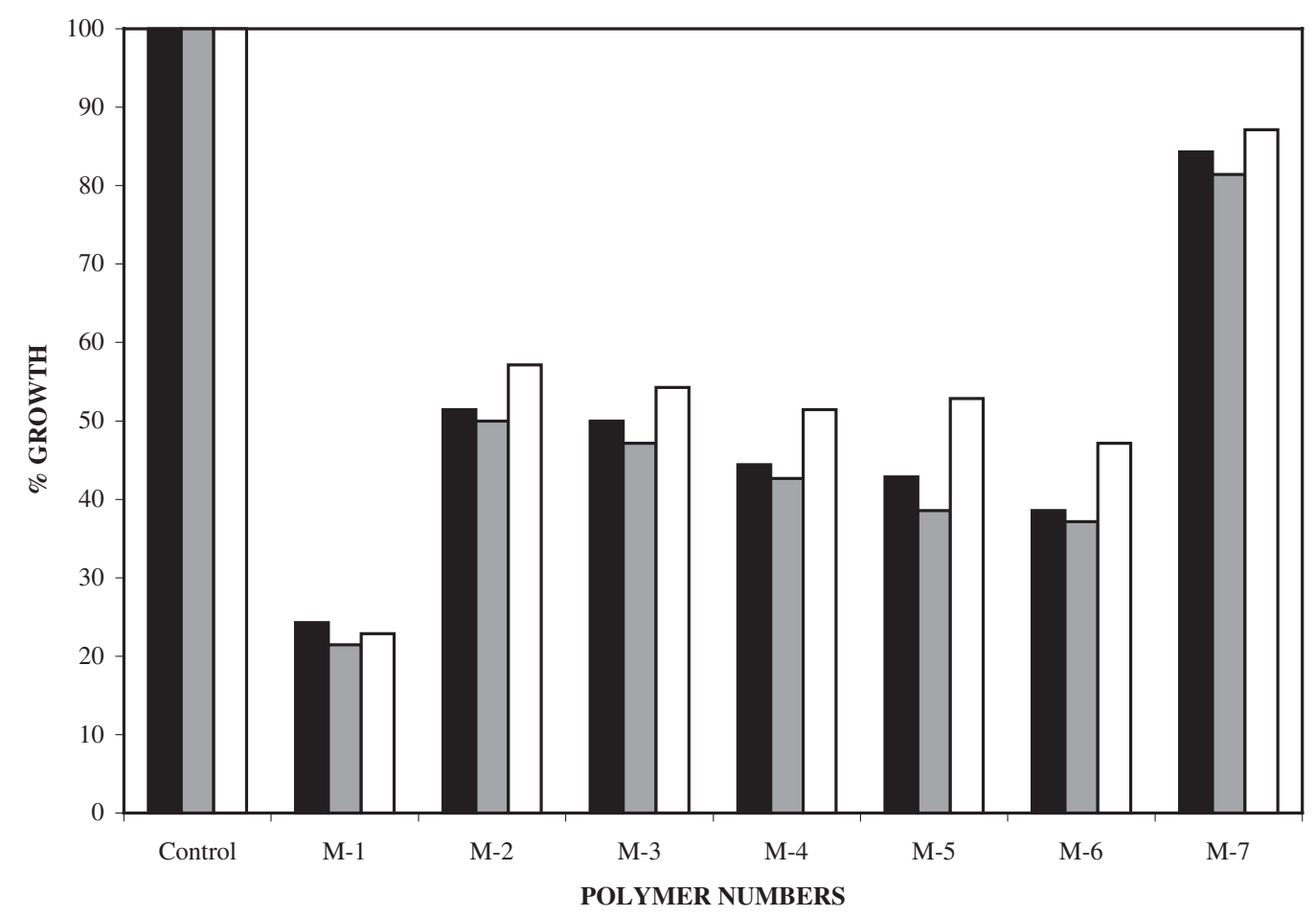

\section{P.stipitis}

$\square$ C.utilis

$\square$ S.cerevisiae

Figure 9. Effect of homo- and copolymers on percentage growth of yeast. 
characterized by spectroscopic methods. The reactivity ratio of CMPM $\left(r_{1}\right)$ is less than that of MMA $\left(r_{2}\right)$ and the product of reactivity ratio was less than one. This shows that the monomers were distributed in the copolymer chain in a random fashion. The number average molecular weight $\left(M_{\mathrm{n}}\right)$ and weight average molecular weight $\left(M_{\mathrm{w}}\right)$ were in the range of 35421 to 45609 and 51892 to 74069 respectively. Thermal analyses showed that all copolymers of CMPM undergo two step decomposition and homo polymers decompose in a single step. The chlorine content of the polymers appears to be the most important component to enhance antimicrobial activity. It is hoped that such chlorine containing copolymers will find use as antimicrobial agents.

\section{REFERENCES}

1. O. Vogl, A. C. Albertsson, and Z. Janovic, Polymer, 26, 1288 (1985).

2. C. S. Selvamalar, T. Krithiga, and S. Nanjundan, React. Funct. Polym., 56, 89 (2003).

3. K. L. Shantha and D. R. K. Harding, Eur. Polym. J., 39, 63 (2003).

4. R. Widmair, T. Schneider, K. Mathauer, and A. Burghardt, PCT Int Appl. WO 37940 (2004), Chem. Abstr., 140, 375685a (2004).

5. G. P. Leisen, European Patent EP 1418187 (2004), Chem. Abstr., 140, 376252u (2004).

6. U. Senthilkumar, K. Ganeshan, and B. S. R. Reddy, J. Polym. Res., 10, 21 (2003).

7. S. T. Oh, H. Yoo, S. Chang, and W. J. Cho, J. Appl. Polym. Sci., 54, 859 (1994).

8. B. T. Patel, R. T. Patel, R. M. Patel, and K. C. Patel, Angew. Macromol. Chem., 263, 21 (1998).

9. T. Narasimhaswang and B. S. R. Reddy, Ind. J. Chem. Technol., 34(B), 607 (1995).
10. S. Nanjundan, A. Penlidis, C. S. Sevamalar, and C. U. Sreekuttan, React. Funct. Polym., 61, 11 (2005).

11. V. Choudhary and A. Mishra, Ind. J. Chem. Technol., 11, 234 (2004).

12. I. Erol, J. Polym. Sci., Part A: Polym. Chem., 42, 3157 (2004).

13. C. Soyakan and I. Erol, J. Polym. Res., 11, 53 (2004).

14. I. Erol, F. Yavuz, and M. Durgan, Polym. J., 36, 303 (2004).

15. K. Yokota, M. Kani, and Y. Ishi, J. Polym. Sci., Part A-1: Polym. Chem., 6, 1325 (1968).

16. T. Narsimhaswamy, S. C. Sumathi, and B. S. R. Reddy, Polymer, 32, 3426 (1991).

17. M. V. Patel, J. N. Patel, A. K. Ray, and R. M. Patel, J. Polym. Sci., Part A: Polym. Chem., 43, 157 (2005).

18. G. H. Stempel, R. P. Cross, and R. P. Mareiolla, J. Am. Chem. Soc., 72, 2299 (1950).

19. M. B. Patel, D. A. Patel, A. K. Ray, and R. M. Patel, Polym. Int., 52, 367 (2003).

20. L. J. Bellamy, "The Infrared Spectra of Complex Molecules," Champman and Hall, London, 1975.

21. N. B. Colthup, L. H. Daly, and S. E. Wiberley, "Introduction to Infrared Spectroscopy," Academic Press, New York, 1990.

22. M. Fineman and S. D. Ross, J. Polym. Sci., 5, 259 (1950).

23. T. Kelen and F. Tudos, J. Macromol. Sci. Chem., A9, 1 (1975).

24. T. Kelen, F. Tudos, and S. Turcansyl, Polym. Bull., 2, 71 (1980).

25. V. R. Gowariker, N. V. Viswanathan, and Sreedhar, "J. Polymer Science," 1st ed., New Age International(P) Limited, New Delhi, 1980, p 204.

26. A. Broido, J. Polym. Sci., Part A-2, 7, 1761 (1969).

27. C. D. Doyle, Anal. Chem., 33, 77 (1961).

28. L. Reich, Die. Makromol. Chemie., 123, 42 (1969).

29. T. O. Sang, S. H. Chang, and J. C. Won, Pollimo, 18, 309 (1994).

30. J. C. U. Pittman and G. A. Stahl, J. Appl. Polym. Sci., 26, 2403 (1981). 